\title{
S layer regeneration in Methanococcus voltae protoplasts
}

\author{
Max Firtel, ${ }^{1}+$ Girishchandra B. Patel $^{2}$ and Terry J. Beveridge ${ }^{1}$ \\ Author for correspondence: Max Firtel. Tel: +1 416978 8896. Fax: +1 4169712410. \\ e-mail: TEMMAX@utcc.utoronto.ca
}

1 Department of Microbiology, College of Biological Sciences, University of Guelph, Guelph, Canada N1G 2W1

2 Institute for Biological Sciences, National Research Council of Canada, Ottawa, Canada K1A OR6

\begin{abstract}
The regeneration of the paracrystalline proteinaceous cell wall (S layer) of the methanogen Methanococcus voltae was examined by electron microscopy. The S layer was removed from the cell surface by exposing the cells to a protoplasting buffer but was completely regenerated by $60-80 \mathrm{~min}$ resuspension in a regeneration medium by some repair mechanism (normal cell generation time is $\mathbf{1 6} \mathrm{h}$ ). The protoplast surface appeared in freeze-fracture to be initially smooth and featureless and remained so for the first $\mathbf{2 0}$ min in regeneration medium. Thereafter, nascent $S$ layer appeared on the surface in the form of paracrystalline patches of various sizes that were distributed over the entire surface. The patches were closely associated with disturbances of the cell surface curvature which may have been caused by electrostatic interactions. The steps leading to the complete regeneration of the $S$ layer could not be followed due to the sampling times used, but presumably the patches grew large enough to contact neighbouring patches and somehow fused into a coherent layer. Other ultrastructural changes occurred to the cell envelope during $S$ layer regeneration, most notably the recurrence of the intramembrane particles of the concave fracture face of the plasma membrane. Flagella remained attached to the protoplasts and were apparently still functional. The major changes to the protein profile of untreated cells, protoplasts and regenerating protoplasts included the loss and resynthesis of polypeptides at the $76 \mathrm{kDa}$ (S layer polypeptide) and $60 \mathrm{kDa}$ (unknown polypeptide) positions. SDS-PAGE evidence indicated that new $S$ layer polypeptides were synthesized $\mathbf{2 0}$ min prior to their appearance as patches on the cell surface. The $S$ layer polypeptide may have been shed from the surface during the early stages of regeneration to form the extracellular sheet-like material observed in large quantity in the regeneration medium. The response of the cell to changes that occur at the cell surface indicates that some feedback mechanism gears the synthesis of $S$ layer and associated envelope components.
\end{abstract}

Keywords: S layer, archaea, protoplasts, freeze-fracture, Methanococcus voltae

\section{INTRODUCTION}

Bacterial cell growth requires the co-ordinated incorporation of new material into each layer of the pre-

\footnotetext{
† Present address: Department of Microbiology, Faculty of Medicine, University of Toronto, Toronto, Ontario, Canada M56 1 A8.

Abbreviations: IP, intramembrane particles; PM, plasma membrane; TEM, transmission electron microscopy.
}

existing envelope. How the cell is able to synthesize and transport the right amount of precursor material to each layer to allow harmonious expansion of the cell surface is not understood. Archaeal cell envelopes can be relatively simple compared to their eubacterial counterparts, and models for cell surface growth studies may be sought among the Archaea. Archaeal cell envelopes often consist solely of a paracrystalline protein monolayer ( $\mathrm{S}$ layer) (reviewed by Messner \& Sleytr, 1992) which is in peripheral contact with the outer face of the plasma 
membrane (PM) (König, 1988). Archaeal S layers contact the PM via inner surface extensions which probably embed in the hydrophobic region of the PM (Hovmöller et al., 1988; Baumeister et al., 1989; Wildhaber \& Baumeister, 1987; Phipps et al., 1990; Firtel et al., 1993). The $\mathrm{S}$ layer is formed from a single type of interlocking polypeptide bound together by noncovalent forces, and is structured to produce transversing channels that are apparent in negative stain transmission electron microscopy (TEM) (Hovmöller et al., 1988) and in ultrafiltration assays (Sára \& Sleytr, 1987a). These layers may be involved in cell morphogenesis and cell septation. The mechanics of septation in cells bearing $\mathrm{S}$ layers as the sole wall component has been recently considered by Pum $e t$ al. (1991) using Metbanocorpusculum sinese as a cell model. The dynamic assembly of the $S$ layer on cell surfaces during growth is little understood, although theoretical considerations dictate that the $\mathrm{S}$ layer must incorporate new material in the lattice at discrete sites which act as growth points (Harris \& Scriven, 1970; Messner et al., 1986; Pum et al., 1991).

In this study, we examined the structural and biochemical changes to the cell envelope due to the removal and subsequent regeneration of the $S$ layer in the marine methanogen Metbanococcus voltae. The cell envelope of $M$. voltae (for a review see Jarrell \& Koval, 1989) is composed of $76 \mathrm{kDa}$ polypeptides packed in a hexagonal lattice with $10 \mathrm{~nm}$ repeat spacing (Koval \& Jarrell, 1987), and a PM mainly composed of $\mathrm{C}_{20}$ biphytanyl ether linked lipids (see Jarrell \& Koval, 1989) that fractures as a bilayer (Beveridge et al., 1993). A dense distribution of intramembrane particles (IP) is revealed on the fractured face of the PM of whole cells (Koval \& Jarrell, 1987). Patel $e t$ al. (1993) found that exposure of mid-exponential-phase $M$. voltae cells to anaerobic protoplasting buffer $(0 \cdot 1 \mathrm{M}$ Tris/ $\mathrm{HCl}$ buffer, $0.05 \mathrm{M} \mathrm{NaCl}, 0.4 \mathrm{M}$ sucrose, $\mathrm{pH} \mathrm{6.6)}$ which contained a concentration of $\mathrm{NaCl}$ suboptimal for growth resulted in the removal of the $\mathrm{S}$ layer polypeptide $(76 \mathrm{kDa})$ and in the formation of viable protoplasts. Unlike protoplasts formed in other archaeal cells, M. voltae protoplasts return to a normal phenotype within a single generation (Patel et al., 1993). The high proportion of regenerating protoplasts make this an ideal system for investigating the dynamics of cell envelope assembly in Archaea. We attempt here to characterize some of the structural and biochemical changes that occur to the cell envelope of regenerating protoplasts.

\section{METHODS}

Stock culture. $M$. voltae PS (NRC 2854) was maintained by weekly transfers $(5 \%, \mathrm{v} / \mathrm{v})$ to $10 \mathrm{ml} \mathrm{BV}$ medium $(60 \mathrm{ml}$ serum vials, $80 \% \mathrm{H}_{2}: 20 \% \mathrm{CO}_{2}$ gas phase, static incubation at $37^{\circ} \mathrm{C}$ ) as described by Patel et al. (1993).

Protoplasting. The anaerobic protoplasting buffer was prepared as described by Patel et al. (1993). A $72 \mathrm{~h}$ stock culture was transferred $(10 \% \mathrm{v} / \mathrm{v})$ to vials containing BV medium and incubated statically $\left(37^{\circ} \mathrm{C}\right.$ for $\left.24 \mathrm{~h}\right)$. The vial headspace $(80 \%$ $\mathrm{H}_{2}: 20 \% \mathrm{CO}_{2}$ ) was repressurized to $69 \mathrm{kPa}$ at 8 and $24 \mathrm{~h}$. Prior to protoplasting, a $2.0 \mathrm{ml}$ cell sample (control) was anaerobically withdrawn by a sterile syringe from each of two $24 \mathrm{~h}$ cultures and processed for EM. The remaining culture was anaerobically transferred to pressurized $\left(\mathrm{N}_{2}\right.$ head space) $15 \mathrm{ml}$ Corex centrifugation tubes modified to accept rubber serum vial closures and the cells were anaerobically sedimented $(7700 \mathrm{~g} ; 10 \mathrm{~min})$ at $22{ }^{\circ} \mathrm{C}$. The spent medium was replaced with $5.0 \mathrm{ml}$ anaerobic protoplasting buffer $(0.1 \mathrm{M}$ Tris $/ \mathrm{HCl}, \mathrm{pH} 6.6,0.05 \mathrm{M} \mathrm{NaCl}$, $0.4 \mathrm{M}$ sucrose) and the cells were gently resuspended. After $2 \mathrm{~min}$ exposure to the buffer, the cells were sedimented $(7700 \mathrm{~g}$; $10 \mathrm{~min})$ and resuspended in anaerobic BV medium containing $1 \%(w / v)$ sterile bovine serum albumin (BSA), i.e. BV/BSA or regeneration medium. The resuspended cells were transferred to serum vials containing BV/BSA (total culture volume $10 \mathrm{ml}$ ) and pressurized to $69 \mathrm{kPa}$ with $\mathrm{H}_{2}: \mathrm{CO}_{2}$, statically incubated at $37^{\circ} \mathrm{C}$, and periodically sampled.

Embedding and thin-sectioning. Samples of regenerating cells were collected every $2 \mathrm{~h}$. The cells were anaerobically transferred to $\mathrm{N}_{2}$-pressurized $15 \mathrm{ml}$ Corex centrifugation tubes fitted with rubber seals, and were killed with $0.2 \mathrm{ml}$ concentrated solution of fixative $(10 \%, v / v$, glutaraldehyde and $8 \%, v / v$, formaldehyde) for $10 \mathrm{~min}$. These cells were harvested $(7700 \mathrm{~g}$; $10 \mathrm{~min}$ ) and fixed in a solution containing $1.0 \%(\mathrm{v} / \mathrm{v})$ giutaraldehyde and $0 \cdot 1 \%(\mathrm{w} / \mathrm{v}) \mathrm{OsO}_{4}$ in $50 \mathrm{mM} \mathrm{HEPES} \mathrm{buffer}$ ( $\mathrm{pH} \mathrm{6.8)} \mathrm{for} 2 \mathrm{~h}$ at $4^{\circ} \mathrm{C}$. The cells were then processed for embedding in LR White resin (medium grade; Marivac), cured in gelatin capsules at $60^{\circ} \mathrm{C}$ overnight, and ultrathin sections were cut on a Reichert-Jung Ultracut $\mathrm{E}$ ultramicrotome and stained with $2 \%(\mathrm{w} / \mathrm{v})$ uranyl acetate $(15 \mathrm{~min})$ and Reynold's lead citrate ( $5 \mathrm{~min})$.

Freeze-fracturing and freeze-etching. Regenerating cells were deposited aerobically into $1.5 \mathrm{ml}$ minivials and centrifuged $(14000 \mathrm{~g} ; 2 \mathrm{~min})$. The concentrated cell pellet was transferred to a gold planchette, quickly frozen by plunging in liquid propane and stored under liquid $\mathrm{N}_{2}$ until placed into a Balzers BA $360 \mathrm{M}$ freeze-etching device. The samples were fractured, etched for $15 \mathrm{~s}$ and shadowed with platinum using an evaporation gun (final pressure at evaporation was $1.1 \times 10^{-3} \mathrm{~Pa}$ ). The replica was treated with $70 \%(\mathrm{v} / \mathrm{v})$ sulfuric acid and $10 \%(\mathrm{v} / \mathrm{v})$ sodium hypochlorite to remove organic material, and collected on 400 mesh copper support grids for viewing.

Sampling. Samples $(2.0 \mathrm{ml})$ were collected from cultures via syringe. Cells were sampled prior to protoplasting (controls) and immediately after resuspending the protoplasts in the regeneration medium $\left(t_{0}\right)$. Thereafter, cells were sampled at $2 \mathrm{~h}$ intervals for thin section embedding (sampled over $14 \mathrm{~h}$ ) or at $20 \mathrm{~min}$ intervals for freeze-fracturing (sampled over $120 \mathrm{~min}$; i.e. $t_{20}, t_{40}, t_{60}, t_{80}, t_{100}$, and $\left.t_{120}\right)$.

Electron microscopy. The specimens were viewed with a Philips EM300 operating at $60 \mathrm{kV}$ under standard conditions, with a liquid nitrogen cold trap in place. The primary magnification for photographing thin-sectioned specimens was $\times 22800$ and for Pt-shadowed specimens was $\times 14148$.

Protein profiles. Cells in the mid-exponential phase of growth were converted to protoplasts as described above. The protoplasts were resuspended in regeneration medium and statically incubated at $37^{\circ} \mathrm{C}$. Samples $(5.0 \mathrm{ml})$ were anaerobically withdrawn, starting immediately after resuspension in BV/BSA medium $\left(t_{0}\right)$ and, thereafter, at 20 min intervals $\left(t_{20}, t_{40}\right.$, and $\left.t_{60}\right)$, cooled on ice to inhibit protein synthesis, and centrifuged. The resulting pellets were resuspended in $0.2 \mathrm{ml}$ double-distilled $\mathrm{H}_{2} \mathrm{O}$ (resulting in immediate cell lysis) and treated with DNase $\left(2 \mu \mathrm{l} 50 \mu \mathrm{g}\right.$ DNase $\mu^{-1}$ in $\left.0 \cdot 15 \mathrm{M} \mathrm{NaCl}\right)$ to reduce viscosity of the lysate. Each sample was diluted $4: 1$ in $5 \times$ concentrated SDS-PAGE sample buffer, heated $\left(95^{\circ} \mathrm{C}\right.$ for $\left.5 \mathrm{~min}\right)$ and $6.25 \mu \mathrm{l}$ of each was then loaded onto $10 \%(\mathrm{w} / \mathrm{v})$ acrylamide gels. The 
gels were electrophoresed and stained as described (Patel et al., 1993).

\section{RESULTS}

\section{Morphology and motility of protoplasts by light microscopy}

The cellular morphology and motility of treated and untreated cells were cursorily examined in wet mounts by phase contrast microscopy. Untreated mid-exponentialphase cells (control) were irregularly shaped cocci, often having a lobed appearance, with variable cell widths. The proportion of motile cells was estimated at approximately
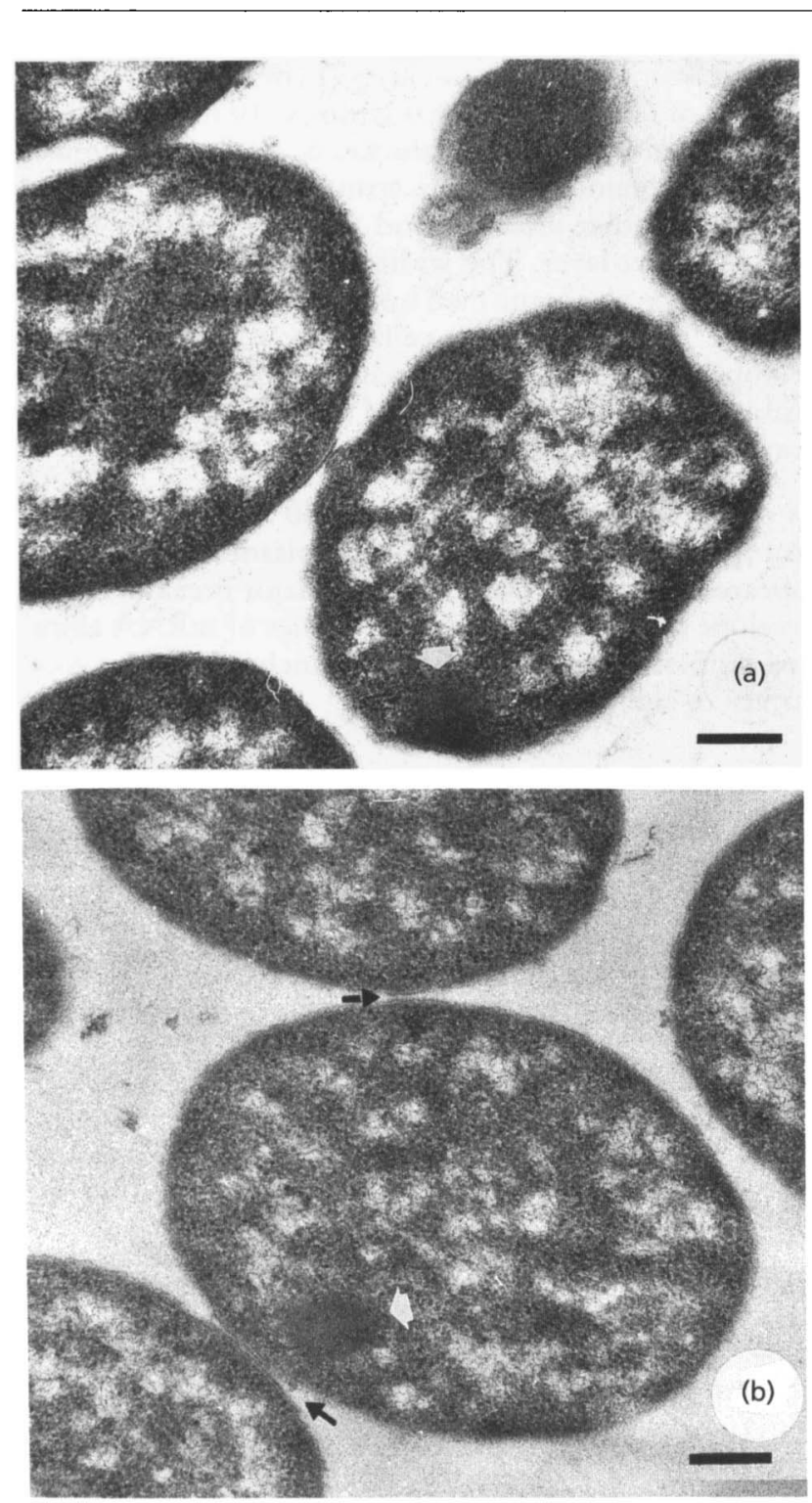

Fig. 1. (a) Thin section of untreated mid-exponential-phase $M$. voltae cells (control). A fine-grained granular body is indicated by the white arrowhead. (b) Thin section of early $M$. voltae protoplasts $\left(t_{0}\right)$. Patches of S-layer remnants are indicated by arrows. A fine-grained granular body is indicated by the white arrowhead. Bars, $200 \mathrm{~nm}$.
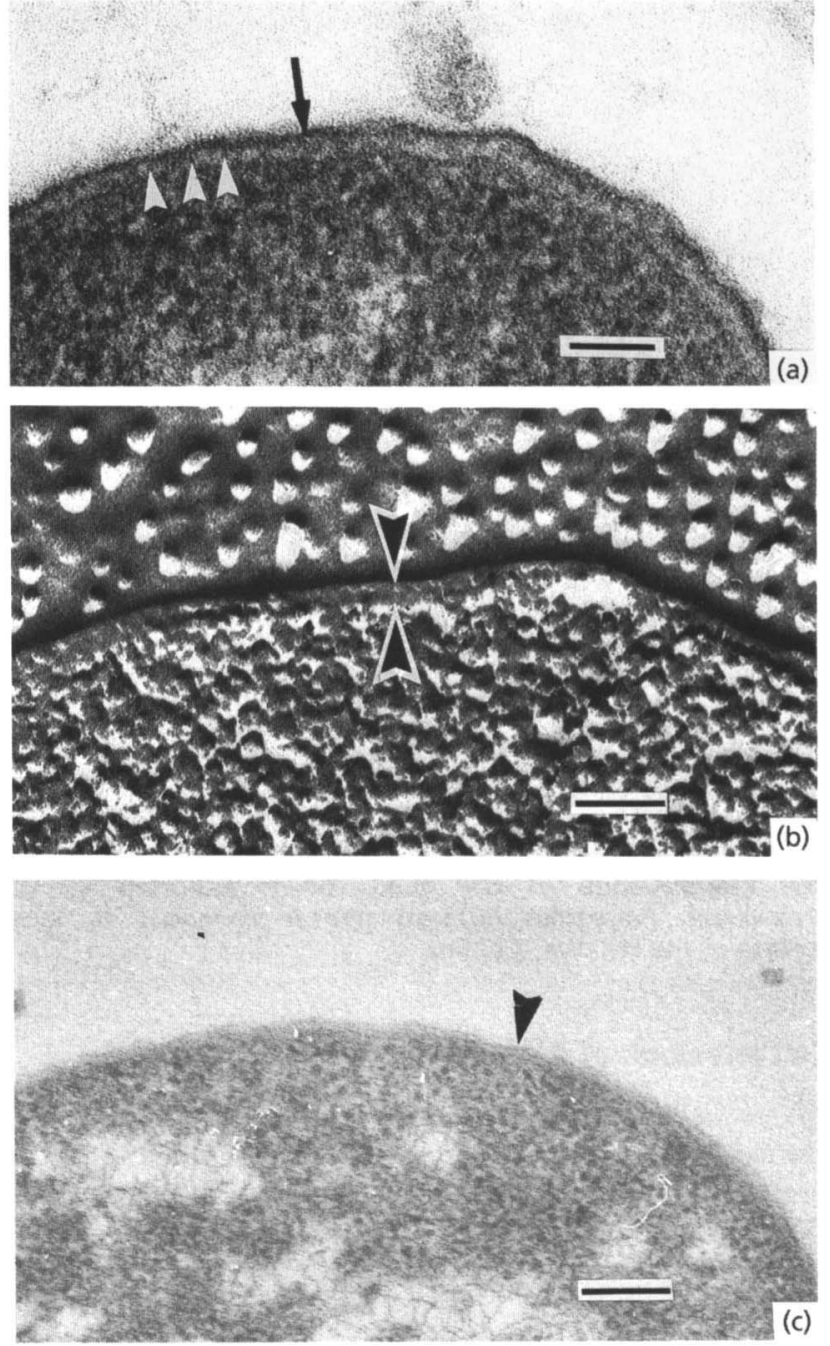

Fig. 2. (a) Highly magnified cross-section of untreated cell envelope. The $S$ layer (arrow) is separated from the thinner inner layer by a lightly stained zone. Transmembrane linkers located in the lightly stained zone are indicated by white arrowheads. (b) Freeze-etched cross-fracture through an untreated cell envelope. The two tightly apposed layers are indicated by arrowheads. (c) Highly magnified cross-section of early protoplast envelope $\left(t_{0}\right)$. The PM is indicated by an arrowhead. Bars, $100 \mathrm{~nm}$.

$15-20 \%$ of the total population. Over $90 \%$ of cells surviving exposure to the protoplasting buffer were spherical with smooth boundaries and were nearly uniform in width. The change in cell morphology was consistent with the removal of the $\mathrm{S}$ layer as previously reported (Patel et al., 1993). The number of motile cells decreased to approximately $5-10 \%$ of the surviving population. Treated cells sampled after $2-14 \mathrm{~h}$ in regeneration medium were morphologically indistinguishable from control cells. Although the cells were not likely to increase in number during the duration of sampling period $(14 \mathrm{~h})$, we still noted by visual inspection an increase in the mass of pellets sampled over time, suggesting the biosynthesis of new material. 


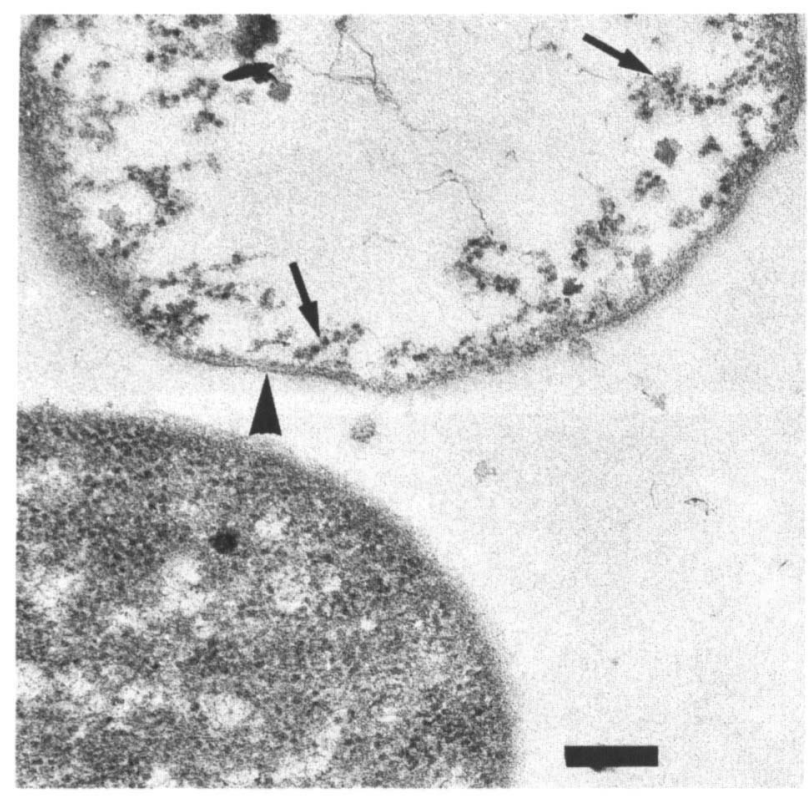

Fig. 3. Cross-section of lysed cell and intact early protoplast $\left(t_{0}\right)$. The PM structure of the lysed cell is indicated by the arrowhead. Polysomes (arrows) appear anchored to inner surface of the PM. Bar, $130 \mathrm{~nm}$.

\section{Cell envelope of early protoplasts}

M. voltae cells were prefixed with a glutaraldehyde/ formaldehyde solution to ensure rapid killing and to help preserve the cellular ultrastructure. Typical control cells are shown in cross-section in Fig. 1(a). The cell ultrastructure was similar to that previously reported by Koval \&
Jarrell (1987): regular- to irregular-shaped cells possessing a heavily stained thick outer layer corresponding to the $\mathrm{S}$ layer. The ultrastructure of protoplasts $\left(t_{0}\right)$ is shown in Fig. 1(b). These protoplasts were nearly uniform in size, regularly shaped with smooth cell boundaries, and possessed approximately $12 \%$ larger cross-sectional area than control cells, probably due to osmotic swelling. The $S$ layer was generally absent, although patches of the $S$ layer could still be observed, particularly in areas where adjacent cells were in direct contact (Fig. 1b).

The cell envelopes of control cells and protoplasts are compared in Fig. 2(a-c). In control cells, the cell envelope consisted of the $\mathrm{S}$ layer (heavily stained outer layer approx. $10 \mathrm{~nm}$ thick) which was separated from the thinner heavily stained inner layer (approx. $8 \mathrm{~nm}$ thick) by a lightly stained intervening layer (hydrophobic region of the PM) of uniform thickness (approx. $10 \mathrm{~nm}$ thick) (Fig. $2 a)$. The entire envelope thickness was approximately 28-30 nm. Stained elements spanned the lightly stained layer at irregular intervals and may connect the $S$ layer with the inner layer. The width and bilayer nature of the cell envelope was confirmed by cross-fracture (Fig. 2b). In contrast to the control cells, the cell boundary in protoplasts was difficult to discern in thin-section; where visible, it appeared as the PM without the associated heavily stained material (Fig. 2c).

As observed in thin-section, about $30 \%$ of the harvested protoplasts were lysed. The cytoplasm of lysed cells appeared to have leaked through a major break in the cell envelope (Fig. 3). Polysomes (stretches of mRNA associated with ribosomes) were found anchored to the inner surface of the PM.
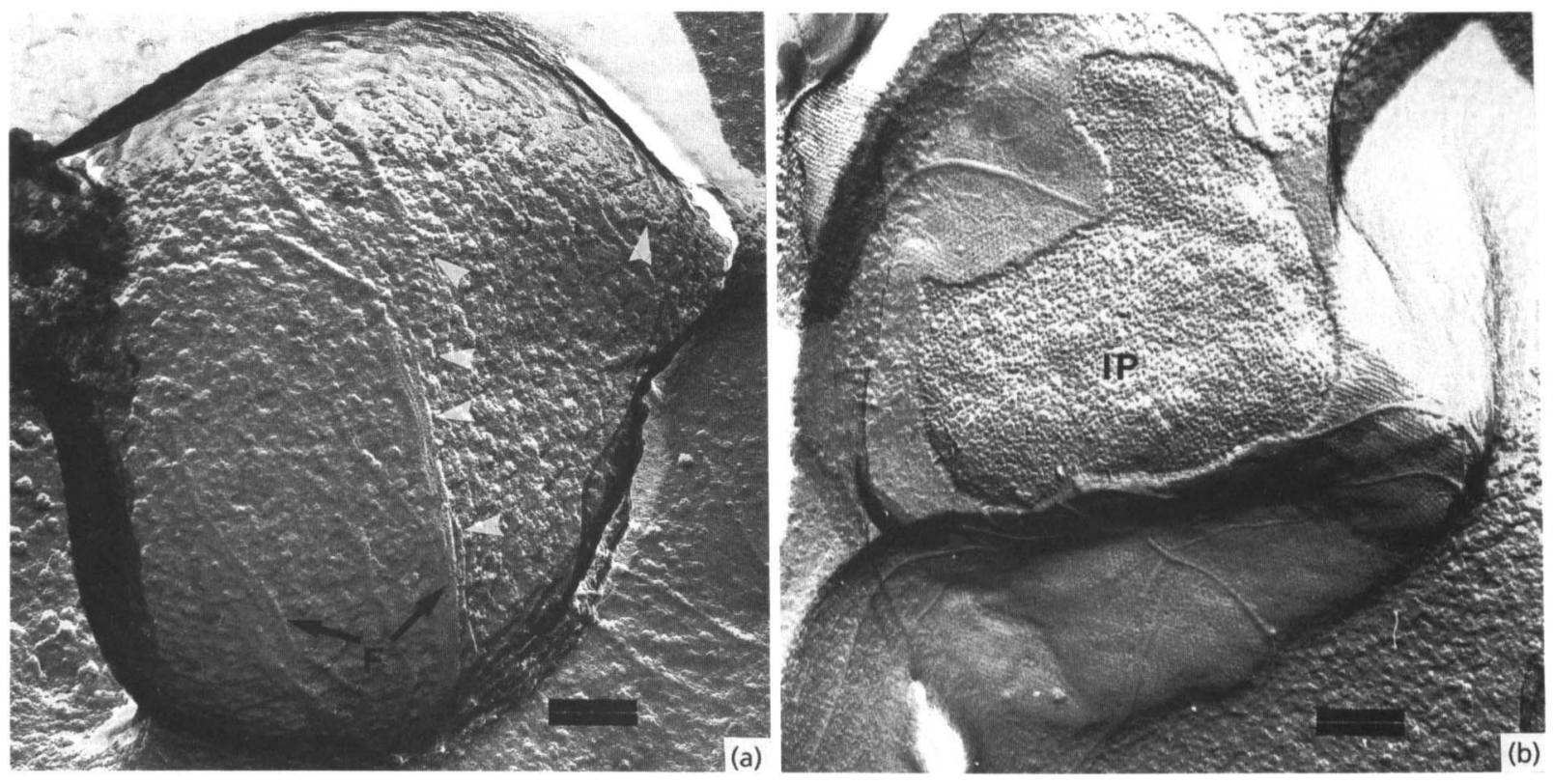

Fig. 4. (a) Replica of protoplast surface after $20 \mathrm{~min}$ in regeneration medium $\left(t_{20}\right)$. The internal features have been exposed by a fracture (outlined by white arrowheads). F, Flagella. (b) Replica of protoplast surface after 80 min in regeneration medium $\left(t_{80}\right)$. A fracture has exposed the intramembrane particles (IP). Bars, $130 \mathrm{~nm}$. 


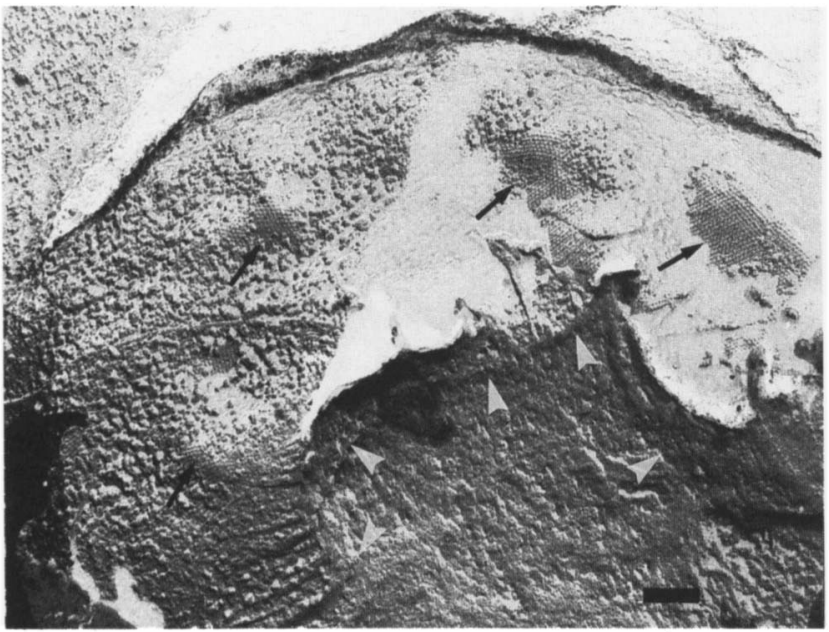

Fig. 5. Replica of a protoplast at the early stages of S-layer regeneration $\left(t_{60}\right)$. Patches of crystalline order are distributed over the cell surface (arrows). The fracture is indicated by white arrowheads. Bar, $130 \mathrm{~nm}$.

\section{The cell envelope during $\mathbf{S}$ layer regeneration}

The surface of protoplasts $\left(t_{0}\right)$ was generally smooth and featureless, indicating the protoplast surface was free of $S$ layer. After $20 \mathrm{~min}$ in regeneration medium, the surface of protoplasts $\left(t_{20}\right)$ had not altered (Fig. 4a). Fracture planes could not be identified since distinct boundary layers were absent. Flagella-bearing protoplasts were common, and flagella were useful for the positive identification of the outer cell surface. Fimbriae were difficult to positively identify and IP were not observed at this stage of regeneration. After $60 \mathrm{~min}$ in regeneration medium, most cell surfaces were covered in crystalline patches. By $80 \mathrm{~min}$, the process of $\mathrm{S}$ layer regeneration on each cell was essentially complete (Fig. 4b). The typical irregularly shaped and contoured cell surface of the untreated control cell, as well as numerous fimbriae and flagella, were evident at this stage. Fracture planes through the cell envelope were common, revealing a dense distribution of IP, each 10.5-10.6 nm wide, underlying the S-layer (Fig. 4b). The distribution of the IP in the fractured faces was nonperiodic as demonstrated by optical diffraction analysis of micrographs (not shown). Cross-fractures were common since the cells had become highly distorted and prone to this type of fracture (not shown). Assuming about 10000 hexameric units are required to cover the cell surface in a coherent lattice (based on the ratio of total surface area of a spherical cell to surface area of the hexameric units of the lattice, calculated using radii of $500 \mathrm{~nm}$ and $5 \mathrm{~nm}$, respectively), the number of hexameric units assembled over the minimal regeneration period (approx. $60 \mathrm{~min}$ ) is approximately 165 hexameric units per cell per min, or 750 individual polypeptides of $76 \mathrm{kDa}$ each per min. Morphologically, cells at $t_{100}$ and $t_{120}$ could not be distinguished from $t_{\mathbf{8 0}}$ cells.

The crystalline patches occurred at multiple sites on the protoplast surface rather than clustered at a single location (Fig. 5) and varied in size and shape. We could not verify

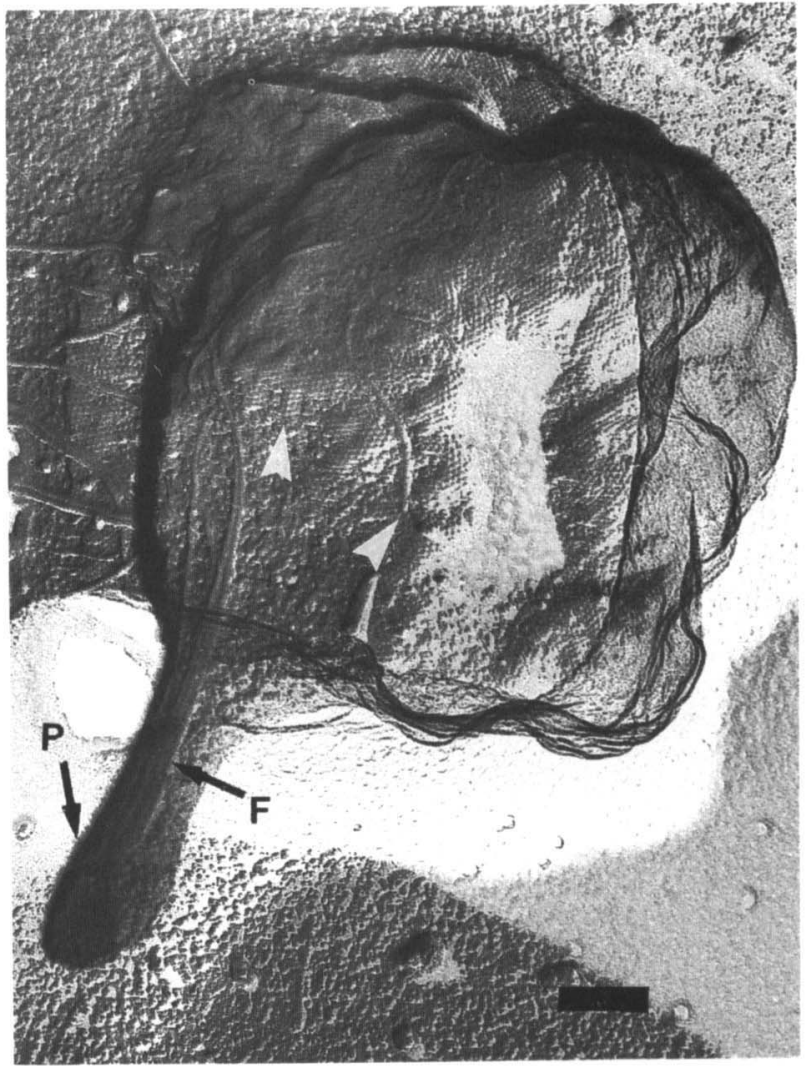

Fig. 6. Replica of a regenerated cell $\left(t_{80}\right)$ with cytoplasmic protrusion (P) and associated flagellar tuft (F). The boundary of the $S$ layer is indicated by arrows. Bar, $130 \mathrm{~nm}$.

if the growth of these patches occurred by boundary growth (i.e. addition of material to the edges of the growing patch) or by 'intussusception' as expected for closed crystal systems (Harris \& Scriven, 1970). The surface underneath the patches was deformed, causing lobes or other surface irregularities, while the surface between these patches was smooth and featureless.

Cells with highly irregular shapes, often due to long projections emanating from the surface, were found throughout the regeneration period. As observed in replicas, flagellar tufts were found associated with these projections (Fig. 6). The cell material appeared to extrude through a gap in the $S$ layer in association with a tuft of flagella which anchored into the membrane at the distal end of the protrusion. It is possible that the propeller action of the rotating flagella may have acted to stretch the elastic PM through the gap.

A significant proportion of cells with regenerated $S$ layers had a bizarre and highly distorted morphology (Fig. 7a), including protrusions, sharply angular surfaces and other distortions. These may indicate structural defects in the lattice.

Large quantities of heavily stained, sheet-like extracellular material, at least $28 \mathrm{~nm}$ thick, were observed in treated cell samples after $4 \mathrm{~h}$ in regeneration medium (Fig. $7 \mathrm{~b}$ ). 

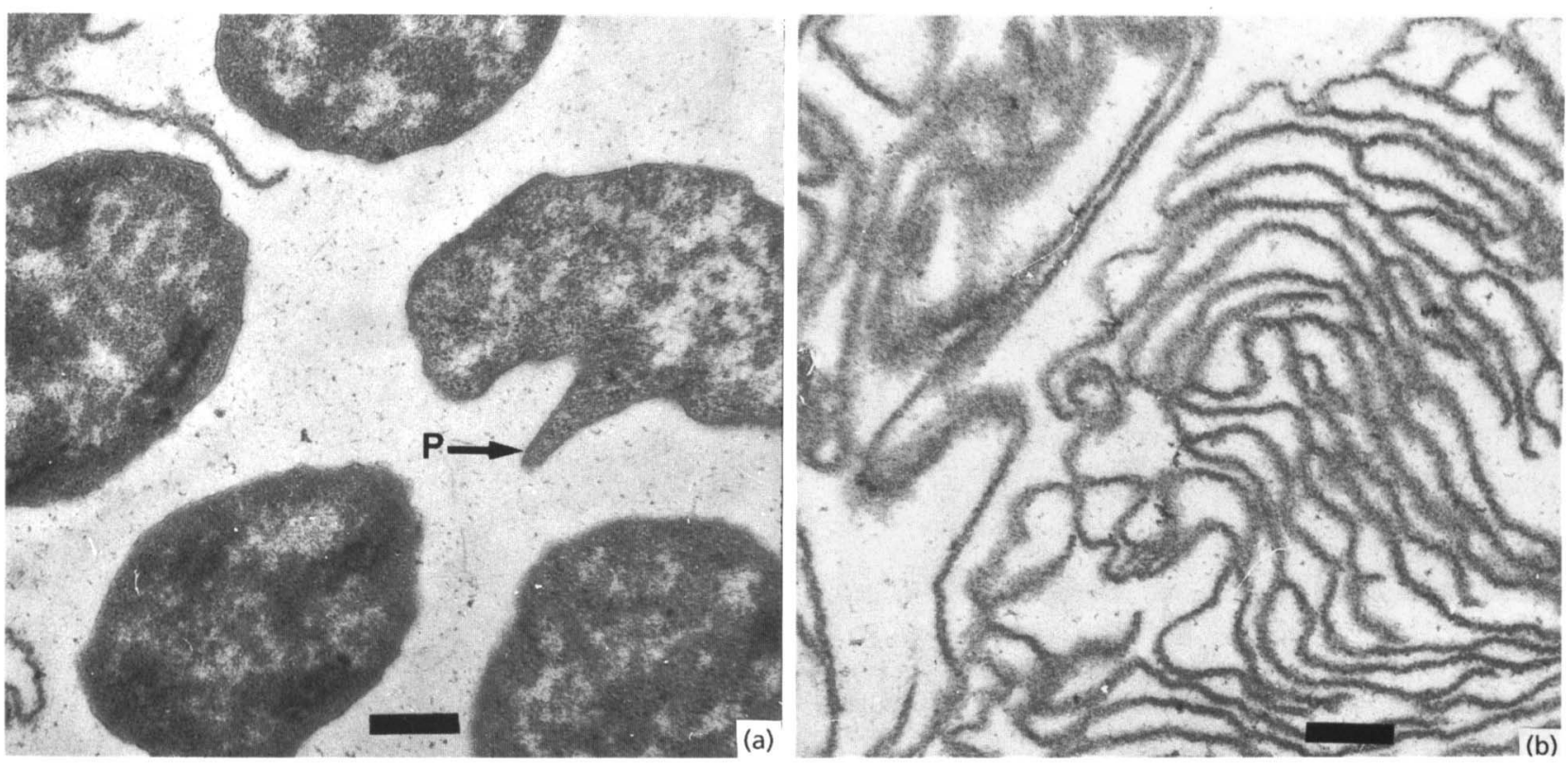

Fig. 7. (a) Cross-section of cells after $10 \mathrm{~h}$ in regeneration medium. P, Protrusion from body of cell. (b) Cross-section of extracellular sheet-like material. Bars, $260 \mathrm{~nm}$.

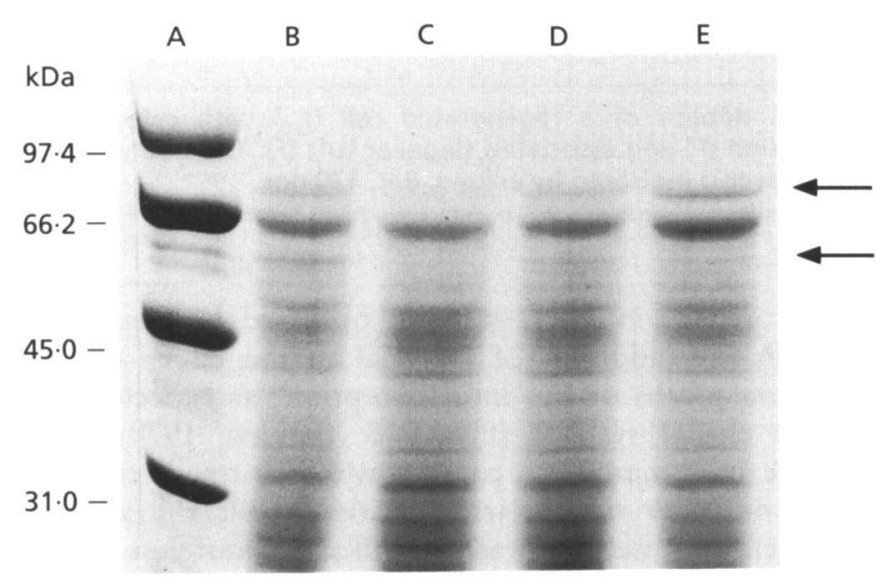

Fig. 8. SDS-PAGE analysis of $M$. voltae crude protein extracts. Lanes: A, molecular mass markers $(\mathrm{kDa}) ; \mathrm{B}$, mid-exponentialphase cells (control cells); $C, t_{0} ; \mathrm{D}, t_{20} ; \mathrm{E}, t_{40}$. Arrows indicate the $76 \mathrm{kDa}$ and $60 \mathrm{kDa}$ polypeptides.

We could not identify periodic structure in the extracellular material in grazing cross-section.

\section{Protein profile alterations during $S$ layer regeneration}

The protein profile was examined by SDS-PAGE (Fig. 8). The major difference between the protoplasts $\left(t_{0}\right)$ and control cells was in the amount of $76 \mathrm{kDa}$ (S layer) and $60 \mathrm{kDa}$ polypeptides. Differences at the region of the BSA band $(66.2 \mathrm{kDa})$ would have been undetected in these experiments due to the presence of BSA in the re- generation medium. The residual $76 \mathrm{kDa}$ band observed at $t_{0}$ may have been due to the traces of $\mathrm{S}$ layer still remaining on the protoplast surface (see Fig. 1b). The protein profile of protoplasts after $20 \mathrm{~min}\left(t_{20}\right)$ was nearly identical to control cells, indicating rapid synthesis of the missing polypeptides. However, the newly synthesized S layer polypeptide was not apparent on the cell surface at this time (see Fig. 4a). This indicates that $\mathrm{S}$ layer polypeptide synthesis occurs at a rate exceeding the rate of lattice assembly, but was prevented from forming a lattice on the cell surface, at least at the early stages of regeneration. The complex structural changes to the early protoplast envelope combined with the temporal association of the $76 \mathrm{kDa}$ and $60 \mathrm{kDa}$ polypeptides suggests that both these polypeptides were based in the cell envelope.

\section{DISCUSSION}

The process of S layer regeneration in $M$. voltae protoplasts is more correctly regarded as a repair process, rather than a growth process, since nearly total turnover of $S$ layer monomers occurs within a fraction of the cell doubling time. S layer regeneration in Lactobacillus belveticus treated with $5 \mathrm{M}$ lithium chloride was similarly regarded by Lortal et al. (1992) as a cellular repair process. Repair may proceed along two distinct paths: (1) a single initiation point leading to a slow forming, but coherent lattice; or (2) multiple initiation points leading to a fast forming, but noncoherent lattice due to mismatches between growing lattice patches. The M. voltae S layer grew from multiple points to rapidly reform the $S$ layer by $60-80 \mathrm{~min}$. Compared to normal $S$ layer growth, in which the equivalent of a new cell surface is synthesized every $16 \mathrm{~h}$ 
(mean generation time; Patel et al., 1993), the rate of repair was more rapid (at least the equivalent of a new cell surface within $80 \mathrm{~min}$ ). The rate of repair probably underestimated the total rate of $S$ layer polypeptide synthesis; the discrepancy between these synthesis rates may be accounted for in the mass of extracellular sheetlike material (Fig. 7b). Extracellular sheet-like material composed of shed S layer polypeptides has been observed to occur with other cell lines (Kist \& Murray, 1984; Smit et al., 1992). Since the $S$ layer grew from multiple points, a period of maturation would likely be needed to allow for some level of correction between mismatched growing crystal patches. However, we were not able to visualize twin crystal boundaries indicative of lattice mismatches since their identification required high resolution image reconstruction techniques (Lembcke et al., 1991) which exceed the limits of the techniques used in this study.

Since the cell regulates $\mathrm{S}$ layer polypeptide synthesis rates according to its need for repair or normal growth, how is the cell able to sense the presence of the $S$ layer on its surface? We propose a sensing mechanism which utilizes the regular structure inherent in the S layer in an inhibitory feedback manner, to control the attachment of $S$ layer synthesizing polysomes to the PM. In this mechanism the $S$ layer would 'imprint' itself on the semifluid lipid portion of the PM which would then incorporate the structural features of the lattice. The 'imprint' may be caused by the hydrophobic domains extending from the inner $S$ layer surface or by inner surface electrostatic charges. The cell may be then be able to locate faults (i.e. growth sites) within the lattice to direct polysomes synthesizing $S$ layer polypeptide to fault regions. In this manner the number and location of polysomes synthesizing $S$ layer polypeptide could be controlled. The disorganization of the PM architecture caused by the complete removal of the S layer may have resulted in the random attachment of polysomes to the PM and the rapid cell surface synthesis.

Compared to control cells, the protoplast cell envelope appeared to have lost material on both sides of the PM, leaving a single bilayer to contain the cytoplasm. To confirm this observation it would be necessary to compare the protein profiles obtained from isolated PM from control cells and protoplasts. Protein analysis of crude cell pellets demonstrated the appearance of the $76 \mathrm{kDa}$ polypeptide (S layer) and a $60 \mathrm{kDa}$ polypeptide of unknown origin. However, a direct physical association between these polypeptides could not be established. A previous report had identified a $60 \mathrm{kDa}$ major polypeptide in the PM of $M$. voltae, but its association with the $76 \mathrm{kDa}$ polypeptide was not determined (Jarrell \& Koval, 1989). It is interesting to note that despite repeated efforts, the $M$. voltae $\mathrm{S}$ layer has not yet been revealed by negative staining (Koval \& Jarrell, 1987; Jarrell \& Koval, 1989), possibly due to associated material which interferes with the penetration of the stain between $S$ layer subunits. The IP of the PM fracture face comprised a significant component of the cell envelope in regenerating cells possessing a coherent $\mathrm{S}$ layer, but were not found in protoplasts. To our knowledge, this study is the first to demonstrate a link between the S layer and IP in $M$. voltae. Unfortunately, little is known of the origin of the IP of $M$. voltae, but their presence has been confirmed in other studies (Beveridge et al., 1993; Koval \& Jarrell, 1987). We tested the possibility that the $S$ layer may impose order on the distribution of the densely packed IP, but were unable to confirm this by diffraction analysis.

The protoplasts synthesized large amounts of $76 \mathrm{kDa}$ polypeptide prior to the observation of $S$ layer patches on their surfaces. Several explanations are possible for the lag period; these include: (1) a period to allow an intracellular pool of $S$ layer polypeptides to accumulate prior to their export to the cell surface for assembly; or (2) the $S$ layer polypeptide was transported to the surface but failed to remain attached to the PM. The latter explanation is attractive because it suggests a possible role for the $60 \mathrm{kDa}$ polypeptide as a membrane anchor for the $\mathrm{S}$ layer and it accounts for the extracellular sheet-like material apparent in thin-sections.

The irregular coccoid form seems to be favoured among methanogens (Garcia, 1990). We note that the surface irregularities present on the $M$. voltae cell surface, such as small scale lobes and mounds, were caused by noncoherent patches of S layer. The mechanism for surface contouring in $M$. voltae may be similar to the mechanism proposed for bleb formation in Gram-negative eubacteria in the presence of exogenous bulky cationic antibiotics (Kadurugamuwa et al., 1993). The surface charge on the inner face of the $M$. voltae $\mathrm{S}$ layer may compete with the polar headgroups of the PM lipids for $\mathrm{Na}^{+}$ions, thereby affecting the packing order of the PM. Electrostatic interactions are important for $\mathrm{S}$ layer stability in extreme halophiles (Sumper, 1993), as well as other organisms (Sára \& Sleytr, 1987b). Alternatively, the hydrophobic domains which are characteristic of $S$ layer structure (Baumeister et al., 1989) when inserted into the PM may restrict lateral flow of the lipid constituents, thereby increasing the rigidity of the PM. This possibility of restricted lateral flow was raised in regard to the thermostability of the PM in thermophiles such as Pyrobaculum islandicum (Phipps et al., 1990).

The motility of early protoplasts was confirmed by light microscopy, indicating that the $S$ layer was not required to stabilize the rotating flagella or for energy transduction. We do not assume, however, that flagella in wall-less cells perform normally (e.g. coordination of flagellar movement and respond to chemotactic stimuli) but at least were able to propel the cell with their rotating action. This was a surprising result since the propeller action of the flagella was presumed to apply enough stress to the cell surface to tear the membrane, unless some relatively rigid wall component was present. The large percentage of cell lysis during protoplasting may have resulted from breaks in the PM caused by flagellar action rather than by osmotic shock. The stress applied to the cell surface by the rotating flagella was evident from the large projections emanating from wall-less regions of the protoplast that were associated with flagella tufts. These projections were consistent with a pulling action on the elastic cell surface. 
Both pushing and pulling forces were found to operate on the cell body of Halobacterium balobium, depending on the rotational direction of the flagella (Alam \& Oesterhelt, 1984).

Protoplast viability in many other archaea is poor, possibly due to an inability to rapidly synthesize new $S$ layer polypeptides in response to the loss of the old $\mathrm{S}$ layer. The rapid regeneration of the $\mathrm{S}$ layer in $M$. voltae substantiates the use of the regenerating $M$. voltae protoplast as a model for examining cell surface growth. The major findings of this study were: (1) S layer regeneration occurs at numerous incorporation points over the protoplast surface rather than at a single major incorporation point; (2) exposure of the cell to protoplasting buffer results in more complex changes to the cell envelope than previously reported (Patel et al., 1993); and (3) a lag period occurs between the synthesis of new $S$ layer polypeptides and the appearance of recognizable nascent $S$ layer on the cell surface.

\section{REFERENCES}

Alam, M. \& Oesterhelt, D. (1984). Morphology, function and isolation of halobacterial flagella. J Mol Biol 176, 459-475.

Baumeister, W., Wildhaber, I. \& Phipps, B. M. (1989). Principles of organization in eubacterial and archaebacterial surface proteins. Can J Microbiol 35, 215-227.

Beveridge, T. J., Choquet, C. G., Patel, G. B. \& Sprott, G. D. (1993). Freeze-fracture planes of methanogen membranes correlate with the content of tetraether lipids. J Bacteriol 175, 1191-1197.

Firtel, M., Southam, G., Harauz, G. \& Beveridge, T. J. (1993). The characterization of the cell wall of the sheathed methanogen Metbanospirillum bungatei GP1 as an S layer. J Bacteriol 175, $7550-7560$

Garcia, J. L. (1990). Taxonomy and ecology of methanogens. FEMS Microbiol Rev 87, 297-308.

Harris, W. F. \& Scriven, L. E. (1970). Function of dislocations in cell walls and membranes. Nature 228, 827-829.

Hovmobller, S., Sjogren, A. \& Wang, D. N. (1988). The structure of crystalline bacterial surface layers. Prog Biophys Mol Biol 51, 131-163.

Jarrell, K. F. \& Koval, S. F. (1989). Ultrastructure and biochemistry of Methanococcus voltae. Crit Rev Microbiol 17, 53-86.

Kadurugamuwa, J. L., Clarke, A. J. \& Beveridge, T. J. (1993). Surface action of gentamicin on Pseudomonas aeruginosa. J Bacteriol 175, 5798-5805.

Kist, M. L. \& Murray, R. G. E. (1984). Components of the regular surface array of Aquaspirillum serpens MW5 and their assembly in vitro. J Bacteriol 157, 599-606.
König, H. (1988). Archaeobacterial cell envelopes. Can J Microbiol 34, 395-406

Koval, S. F. \& Jarrell, K. F. (1987). Ultrastructure and biochemistry of the cell wall of Methanococcus voltae. J Bacteriol 169, 1298-1306.

Lembcke, G., Durr, R., Hegerl, R. \& Baumeister, W. (1991). Image analysis and processing of an imperfect two-dimensional crystal: the surface layer of the archaebacterium Sulfolobus acidocaldarius reinvestigated. J Microsc 161, 263-278.

Lortal, S., van Heijenoort, J., Gruber, K. \& Sleytr, U. B. (1992). Slayer of Lactobacillus belveticus ATCC 12046: isolation, chemical characterization and re-formation after extraction with lithium chloride. J Gen Microbiol 138, 611-618.

Messner, P. \& Sleytr, U. B. (1992). Crystalline bacterial cell-surface layers. Adv Micrab Pbysiol 33, 213-273.

Messner, P., Pum, D., Sára, M., Stetter, K. O. \& Sleytr, U. B. (1986). Ultrastructure of the cell envelope of the archaebacteria Thermoproteus tenax and Thermoproteus neutropbililus. J Bacteriol 166, 1046-1054.

Patel, G. B., Choquet, C. G., Nash, J. H. E. \& Sprott, G. D. (1993). Formation and regeneration of Methanococcus voltae protoplasts. Appl Environ Microbiol 59, 27-33.

Phipps, B. M., Engelhardt, H., Huber, R. \& Baumeister, W. (1990). Three-dimensional structure of the crystalline protein envelope layer of the hyperthermophilic archaebacterium Pyrobaculum islandicum. J Struct Biol 103, 152-163.

Pum, D., Messner, P. \& Sleytr, U. B. (1991). Role of the $S$ layer in morphogenesis and cell division of the archaebacterium Methanocorpusculum sinese. J Bacteriol 173, 6865-6873.

Sára, M. \& Sleytr, U. B. (1987a). Molecular sieving through S layers of Bacillus stearothermophilus strains. J Bacteriol 169, 4092-4098.

Sára, M. \& Sleytr, U. B. (1987b). Charge distribution on the S layer of Bacillus stearothermophilus NRS 1536/3c and importance of charged groups for morphogenesis and function. J Bacteriol 169, 2804-2809.

Smit, J., Engelhardt, H., Volker, S., Smith, S. H. \& Baumeister, W. (1992). The S-layer of Caulobacter crescentus: Three-dimensional image reconstruction and structural analysis by electron microscopy. J Bacteriol 174, 6527-6538.

Sumper, M. (1993). S-layer glycoproteins from moderately and extremely halophilic archaeobacteria. In Advances in Bacterial Paracrystalline Surface Layers (NATO ASI Series A: Life Sciences vol. 252), pp. 109-117. Edited by T. J. Beveridge \& S. F. Koval. New York: Plenum Press.

Wildhaber, I. \& Baumeister, W. (1987). The cell envelope of Thermoproteus tenax. Three-dimensional structure of the surface layer and its role in shape maintenance. EMBO J 6, 1475-1480.

Received 1 September 1994; revised 18 November 1994; accepted 1 December 1994. 